\title{
Evaluation of conservation and trade status of marine ornamental fish harvested from Pangandaran Coastal Waters, West Java, Indonesia
}

\author{
AGUS NURYANTO", DIAN BHAGAWATI, KUSBIYANTO \\ Faculty of Biology, Universitas Jenderal Soedirman. Jl. Dr. Soeparno 63, Purwokerto, Banyumas 53122, Central Java, Indonesia, Tel.:.+62-281-638794, \\ Fax.: +62-281-631700, •email: anuryanto2003@yahoo.com
}

Manuscript received: 22 November 2019. Revision accepted: 14 January 2020.

\begin{abstract}
Nuryanto A, Bhagawati D, Kusbiyanto. 2020. Evaluation of conservation and trade status of marine ornamental fish harvested from Pangandaran Coastal Waters, West Java, Indonesia. Biodiversitas 21: 512-520. Pangandaran coastal waters are among the main supply areas of marine ornamental fish in Indonesia. However, no scientific data are available on the conservation and trade status of marine ornamental fish harvested in this region. This study aimed to evaluate the diversity, conservation, and trade status of marine ornamental fish species harvested from Pangandaran coastal waters. Fish were collected during surveys conducted in March, April, July, and September 2019. Species were identified by referring to the available guidance books. The conservation status was analyzed according to the IUCN database, whereas the trade status was evaluated based on the CITES database. A total of 107 marine ornamental fish species from 32 families and eight orders was obtained. The two out of these 107 species had an unresolved conservation status, whereas 24 species were listed as Not Evaluated, 80 species were listed as Least Concern, and one species was listed as Vulnerable by IUCN. Two species had an unknown trade status, whereas 104 species were listed as Not Evaluated and one species was listed in Appendix II of CITES. Our data prove that Pangandaran coastal waters have a high potential for supplying marine ornamental fish, with most of the species listed as having a Not Evaluated or Least Concern status. Most of the species identified were also categorized as having a Not Evaluated trade status.
\end{abstract}

Keywords: Aquarium trade, marine, morphology, ornamental fish, Pangandaran

\section{INTRODUCTION}

Pangandaran District in the West Java Province of Indonesia directly faces the Indian Ocean as its southern border. It has approximately $91 \mathrm{~km}$ of coastline and an area of 67,340 $\mathrm{km}^{2}$ (Central Bureau of Statistics 2018). Pangandaran has a high potential as a marine fishery (Firmansyah et al. 2018). The marine fish capture levels in Pangandaran District were 10,872,929.54 tons in 2016. This production capacity only includes a calculation of fish and shrimp destined for consumption; e.g., various shrimp species, lobster, red snapper, white snapper, groupers, white snapper, various shark species, black pomfret, white pomfret, various mackerel species, and other fish species. There are however no specific records available on the total yearly catch of marine ornamental fish from Pangandaran coastal waters (Central Bureau of Statistics 2018).

Marine ornamental fish have become a popular commodity as the decorative animal industry has increased worldwide (Wabnitz et al. 2003). In Indonesia, the export of marine ornamental fish started in the 1970s (Wood 2001). At the present time, after the Philippines, Indonesia is a major contributor to this trade (Shuman et al. 2004; Nijman 2010) and in fact, supplies a greater number of species than the Philippines (Rhyne et al. 2012a; 2012b). Nevertheless, the marine ornamental fish trade in Indonesia is mostly supported by natural collection (Nijman 2010). It is widely understood that the marine aquarium trade harms the ecosystem (Tlusty 2002) because the collection of target species mostly relies on the use of poisonous chemicals to keep the fish alive (Halim 2002; Rubec et al. 2001). Furthermore, the controversial use of destructive fishing methods raises a concern about the sustainable use of these wildlife resources due to over-fishing (Ziemann 2001), especially for rare and endemic species (Gertzen et al. 2008; Jones et al. 2008; Lunn and Moreau 2004).

It is feared that the fish poisoning method is also used to harvest marine ornamental fish from Pangandaran coastal waters thereby threatening the target species. This is because the use of poisons during the capture of marine ornamental fish is a common practice across Indonesia (Pet-Soede and Erdman 1998). Nevertheless, no current data are available on the diversity of marine ornamental fish harvested from Pangandaran coastal waters. The only available data related to the marine ornamental species on the southern coast of West Java comes from a report in 1988, which reported a total of 98 fish species (Prahoro and Adrim 1988). However, detailed information on which species were harvested as ornamental species within that report was not described. Other reports from Mayunar (1996) stated that 55 fish species were sold in the international aquarium trade, while Fujita et al. (2013) stated that 21 fish species from Indonesia were sold in the international aquarium trade. The most recent report from Wahyudin (2011) only focused on marine ornamental fish from the southern coast of Sukabumi District, but only at the family level. These data might lead to an underestimate of fish diversity and the nature of marine ornamental fish 
diversity on the southern coast of West Java or even from the Pangandaran Region. It is well-known that Indonesian waters have a high fish diversity and account for a total of 47777 fish species that inhabit freshwater, brackish, and marine waters (Froese and Pauly 2019).

None of these earlier studies addressed the conservation and trade status of marine ornamental fish harvested from Pangandaran coastal waters. Data describing the species diversity, conservation, and trade status of marine ornamental fish harvested from this region are therefore essential for the sustainable management of these resources. The present study aimed to evaluate the diversity, conservation, and trade status of marine ornamental fish harvested from Pangandaran coastal waters.

\section{MATERIALS AND METHODS}

\section{Study area and time}

The present study used a survey method with incidental sampling. Fish samples were collected in Bojongsalawe Village, Sub-district of Parigi on the Pangandaran District, West Java, Indonesia (Figure 1). Fish samples were collected six times in March, April, July, and September 2019. Therefore, the data is available for both of the monsoon seasons (east and west monsoons).

\section{Sample collection and preservation}

Ornamental fish specimens were bought from the first middleman who collected the ornamental fish directly from the fishermen. The first middleman in Bojongsalawe Village was chosen because he continuously collects and sells ornamental fish from Pangandaran coastal waters on a middle scale. The fish samples were photographed using an 8-megapixel camera. Direct photography was performed in order to obtain the original color and color pattern data since both data are crucial diagnostic characteristics used for species identification in marine ornamental fish. All fish samples were preserved in ethanol $70 \%$.

\section{Identification}

Species identity was determined based on color, color pattern, and the meristic characteristics of each fish sample and compared to the description of each species in Allen and Erdmann (2012). In the case of juvenile samples, where no picture was available in Allen and Erdmann (2012), identification process was performed using Fish Base database and this data was also used to verify the identification of all species (Froese and Pauly 2019). The geographic distribution of the species was also checked in the distribution maps as available in www.aquamaps.org (version of Aug. 2016. Web accessed on 26 May 2019).

\section{Data analysis}

The data on species diversity was analyzed mathematically as species richness, which refers to the total number of species collected and traded during the study. Data on the number of species are presented in a table; data on the family level are presented in a bar chart, while data on the order level are presented as a pie chart. The conservation status of each species was determined according to the International Union for Conservation of Nature (IUCN) through the IUCN's website. The IUCN categorize organisms as Not Evaluated (NE), Data Deficient (DD), Least Concern (LC), Near Threatened (NT), Vulnerable (VU), Endangered (EN), Critically Endangered (CR), Extinct in the Wild (EW), and Extinct (E) (https: //www.iucn.org/resources/conservationtools/iucn-red-list-threatened-species). The trade status of each fish was also analyzed online using the Convention on International Trade in Endangered Species (CITES) webpage. The trade status at the local market level was obtained from an in-depth interview with the first middlemen.
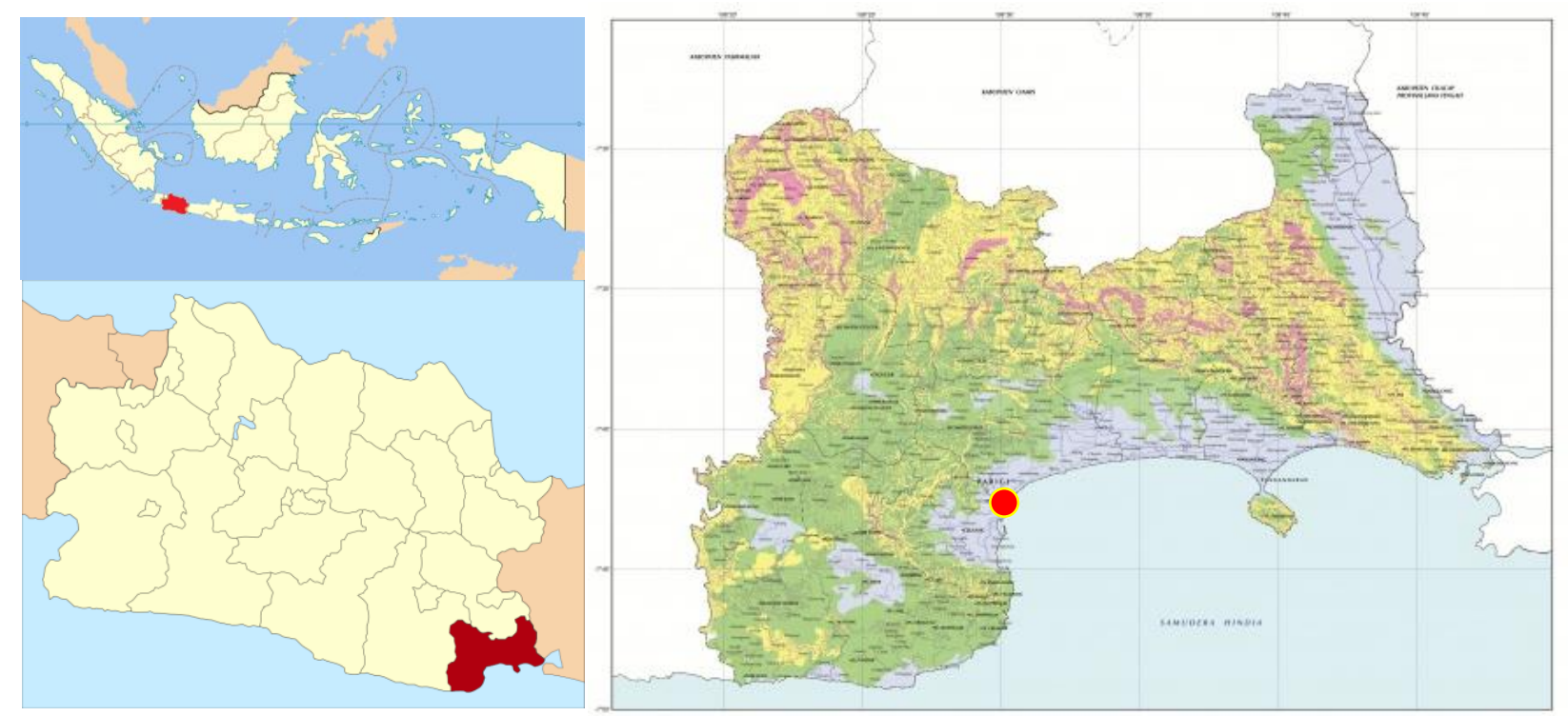

Figure 1. Schematic map of Pangandaran District, West Java, Indonesia with Bojongsalawe Village as a sampling site (•) 


\section{RESULTS AND DISCUSSION}

\section{Species diversity}

A total of 332 individual fish that were collected and traded as ornamental species were obtained during this study and the samples were placed into 107 fish species from 32 families and eight orders. The list of species, families and orders is shown in Table 1. The number of species obtained indicated that there was a high degree of species variability in the marine ornamental fish harvested from Pangandaran coastal waters. At the same time, our data proved that the southern coast of Pangandaran offers a high potential as a marine ornamental fish resource that could support the livelihood of communities in the region.

No data are available describing marine ornamental fish diversity with particular reference to a specific locality in Indonesia. Only two data types are available for marine ornamental fish in Indonesia. The first data that is available describes import to the United States of America (USA) (Rhyne et al. 2012a), which accounted for 997 ornamental fish species imported from Indonesia. The other data describe ornamental fish species targeted for export from Indonesia, e.g., 21 species (Fujita et al. 2013) or 55 species (Mayunar 1996). Therefore, we could not make a comparison of marine ornamental fish diversity according to locality per se. Comparison to an older previous study from Raksodihardjo-Lilley and Lilley (2007) showed that the marine ornamental fish species targeted by fishermen in Pangandaran coastal waters are much more variable than those targeted by fishermen in Bali. Marine ornamental fish diversity as observed in this study was also higher than that reported in the study from Fujita et al. (2013) which counted only 21 species targeted for the aquarium trade, while in this study we found that a total of 107 fish species were harvested and traded in the aquarium market from Pangandaran coastal waters. A possible reason for this difference is that Reksodihardjo-Liley and Liley (2007) and Fujita et al. (2013) only counted the top fish species for international trade. However, the ornamental fish harvest and trade on the southern coast of Pangandaran are conducted to fulfill local, national, and international market demands. Therefore, this study obtained a higher number of species than those in the Reksodihardjo-Liley and Liley (2007) and Fujita et al. (2013) studies.

In contrast, the total number of species that were observed during this study was much lower than the number of species reported by Rhyne et al. (2012a) for import to the USA. The total number of species in this study accounted for approximately $10.73 \%$ (107/997) of the total species imported to the USA in 2005. The large difference between this study and the study by Rhyne et al. (2012a) could be due to the difference in study coverage. In this study, we collected a sample from a narrow area in Pangandaran coastal waters, while Rhyne et al. (2012a) reported data from all over Indonesia and over several years. Pangandaran represents only $0.11 \%$ of the total Indonesian coastline $(91 \mathrm{~km} / 80,000 \mathrm{~km})$. It is important to note that the Pangandaran coastline harbors about $10.73 \%$ of the total marine ornamental fish species imported to the USA from Indonesia. Therefore, a total of 107 ornamental fish is a considerably large number for such a narrow area as the Pangandaran coastal waters.

As discussed previously, no study has had a special emphasis on marine ornamental fish harvested from a particular location in Indonesia. The lack of other local data, therefore, makes a site by site comparison difficult. A site by site comparison is only possible with other studies about the fish communities conducted in several localities. In these comparisons, we found variable results. We found that in this study we obtained a higher number of fish species than that reported by Hastuty et al. (2014) in Weh Island, Aceh; Yusuf (2013) in Karimunjawa National Park, Java Sea; and Fadli et al. (2018) in Ulee Lheue breakwater, Banda Aceh. The present study obtained even greater fish diversity than reported by Fadli et al. (2012), although they sampled all types of coral fish (ornamental and nonornamental species). In the second comparison, we obtained a lower number of fish species than in the study from Sahetapy et al. (2018) in Tuhaha Bay, Saparua Island, Maluku Province; Madduppa et al. (2013) in Thousand Islands, Java Sea; Jakarta; and Unsworth et al. (2007) in Wakatobi Marine National Park, Southeast Sulawesi.

The higher species numbers obtained in this study compared to the study from Hastuty et al. (2014), Yusuf (2013) and Fadli et al. (2018) indicate that Pangandaran has a high potential for supplying marine ornamental fish species and provides additional support for it to be able to fulfill the livelihood needs of the community in this district. The differences between our study and those of the previous studies from Sahetapy et al. (2018), Madduppa et al. (2013), and Unsworth et al. (2007) could be due to the different focus of our study. This study only focused on marine ornamental fish that are collected from the Pangandaran coastline and traded in the aquarium trade, and so might not cover all ornamental species, whereas these three previous studies collected all marine species in their natural habitat. Therefore it is reasonable that we obtained a lower number of species than Sahetapy et al. (2018), Madduppa et al. (2013), and Unsworth et al. (2007). Nevertheless, our data are valuable for the management of marine resources on the southern coast of Pangandaran, with a special emphasis on ornamental fish. This is because the marine ornamental fish trade has different characteristics compared to the consumable fish trade. Addressing the management of marine ornamental fisheries requires scientific data that address species diversity, conservation, and trade status of the species harvested in Pangandaran coastal waters, which is vital as a scientific basis for the sustainable management of the marine ornamental trade in Pangandaran District.

At the family level, Pomacentridae was the most abundant family with 18 species, followed by Chaetodontidae with 12 species and Acanthuridae and Labridae, with 11 species each. The remaining families had ranged from 1-7 species. The detailed data on species numbers for each family are presented in Figure 2. 
Table 1. Conservation and trade status of ornamental fish species collected and traded from Pangandaran coastal waters

\begin{tabular}{|c|c|c|c|c|}
\hline Order & Family & Species & $\begin{array}{l}\text { Conservation } \\
\text { status }\end{array}$ & CITES \\
\hline \multirow[t]{7}{*}{ Anguilliformes } & \multirow[t]{7}{*}{ Muraenidae } & Echidna nebulosa & $\mathrm{LC}$ & $\mathrm{NE}$ \\
\hline & & Echidna polyzona & $\mathrm{LC}$ & $\mathrm{NE}$ \\
\hline & & Echidna xanthopilos & $\mathrm{NE}$ & $\mathrm{NE}$ \\
\hline & & Gymnothorax favagineus & $\mathrm{LC}$ & $\mathrm{NE}$ \\
\hline & & Gymnothorax javanicus & $\mathrm{LC}$ & $\mathrm{NE}$ \\
\hline & & Gymnothorax sp. & unknown & unknown \\
\hline & & Uropterygius polyspilus & $\mathrm{LC}$ & $\mathrm{NE}$ \\
\hline Batrachoidiformes & Batrachoididae & Allenbatrachus grunniens & $\mathrm{NE}$ & $\mathrm{NE}$ \\
\hline \multirow[t]{5}{*}{ Beryciformes } & \multirow{5}{*}{ Holocentridae } & Myripristis berndti & $\mathrm{LC}$ & $\mathrm{NE}$ \\
\hline & & Myripristis hexagona & $\mathrm{LC}$ & $\mathrm{NE}$ \\
\hline & & Sargocentron diadema & $\mathrm{LC}$ & $\mathrm{NE}$ \\
\hline & & Sargocentron spiniferum & $\mathrm{LC}$ & $\mathrm{NE}$ \\
\hline & & Sargocentron caudimaculatum & $\mathrm{LC}$ & $\mathrm{NE}$ \\
\hline Lophiiformes & Antennariidae & Antennatus tuberosus & $\mathrm{NE}$ & $\mathrm{NE}$ \\
\hline \multirow{49}{*}{ Perciformes } & \multirow{11}{*}{ Acanthuridae } & Acanthurus nigricauda & $\mathrm{LC}$ & NE \\
\hline & & Acanthurus maculiceps & $\mathrm{LC}$ & $\mathrm{NE}$ \\
\hline & & Acanthurus nigrofuscus & $\mathrm{LC}$ & $\mathrm{NE}$ \\
\hline & & Acanthurus nigricans & $\mathrm{LC}$ & $\mathrm{NE}$ \\
\hline & & Acanthurus dussumieri & $\mathrm{LC}$ & $\mathrm{NE}$ \\
\hline & & Acanthurus xanthopterus & $\mathrm{LC}$ & $\mathrm{NE}$ \\
\hline & & Acanthurus lineatus & $\mathrm{LC}$ & $\mathrm{NE}$ \\
\hline & & Acanthurus pyroferus & $\mathrm{LC}$ & $\mathrm{NE}$ \\
\hline & & Naso unicornis & $\mathrm{LC}$ & $\mathrm{NE}$ \\
\hline & & Naso lituratus & $\mathrm{LC}$ & $\mathrm{NE}$ \\
\hline & & Paracanthurus hepatus & $\mathrm{LC}$ & $\mathrm{NE}$ \\
\hline & \multirow[t]{3}{*}{ Apogonidae (3) } & Ostorhinchus novemfasciatus & $\mathrm{NE}$ & $\mathrm{NE}$ \\
\hline & & Fowleria flammea & $\mathrm{NE}$ & $\mathrm{NE}$ \\
\hline & & Sphaeramia orbicularis & NE & NE \\
\hline & \multirow[t]{4}{*}{ Blenniidae (4) } & Aspidonotus taeniatus & $\mathrm{LC}$ & $\mathrm{NE}$ \\
\hline & & Aspidonotus sp & unknown & unknown \\
\hline & & Blenniella interrupta & LC & $\mathrm{NE}$ \\
\hline & & Plagiotremus rhinorhynchos & $\mathrm{LC}$ & $\mathrm{NE}$ \\
\hline & Carangidae (1) & Gnathanodon speciosus & $\mathrm{LC}$ & $\mathrm{NE}$ \\
\hline & Centrogenyidae (1) & Centrogenys vaigiensis & $\mathrm{LC}$ & $\mathrm{NE}$ \\
\hline & \multirow[t]{12}{*}{ Chaetodontidae (12) } & Chaetodon decussatus & $\mathrm{LC}$ & NE \\
\hline & & Chaetodon kleinii & $\mathrm{LC}$ & $\mathrm{NE}$ \\
\hline & & Chaetodon citrinellus & $\mathrm{LC}$ & $\mathrm{NE}$ \\
\hline & & Chaetodon ephippium & $\mathrm{LC}$ & $\mathrm{NE}$ \\
\hline & & Chaetodon rafflesii & $\mathrm{LC}$ & $\mathrm{NE}$ \\
\hline & & Chaetodon collare & $\mathrm{LC}$ & $\mathrm{NE}$ \\
\hline & & Chaetodon trifasciatus & $\mathrm{LC}$ & $\mathrm{NE}$ \\
\hline & & Chaetodon lunula & $\mathrm{LC}$ & $\mathrm{NE}$ \\
\hline & & Chaetodon auriga & $\mathrm{LC}$ & $\mathrm{NE}$ \\
\hline & & Chaetodon vagabundus & $\mathrm{LC}$ & $\mathrm{NE}$ \\
\hline & & Heniochus diphreutes & $\mathrm{LC}$ & NE \\
\hline & & Heniochus acuminatus & $\mathrm{LC}$ & $\mathrm{NE}$ \\
\hline & Cirrhitidae (1) & Paracirrhites fosteri & $\mathrm{LC}$ & $\mathrm{NE}$ \\
\hline & \multirow[t]{2}{*}{ Ephippidae (2) } & Platax boersii & NE & $\mathrm{NE}$ \\
\hline & & Platax orbicularis & $\mathrm{LC}$ & $\mathrm{NE}$ \\
\hline & Gobiidae (1) & Amblygobius sphynx & $\mathrm{LC}$ & $\mathrm{NE}$ \\
\hline & Haemulidae (1) & Plectorhinchus vittatus & $\mathrm{LC}$ & NE \\
\hline & Kuhliidae (1) & Kuhlia mugil & $\mathrm{LC}$ & $\mathrm{NE}$ \\
\hline & \multirow[t]{11}{*}{ Labridae (11) } & Gomphosus caeruleus & $\mathrm{LC}$ & $\mathrm{NE}$ \\
\hline & & Choerodon anchorago & $\mathrm{LC}$ & $\mathrm{NE}$ \\
\hline & & Halichoeres nigrescens & $\mathrm{LC}$ & $\mathrm{NE}$ \\
\hline & & Halichoeres marginatus & $\mathrm{LC}$ & $\mathrm{NE}$ \\
\hline & & Halichoeres miniatus & $\mathrm{LC}$ & $\mathrm{NE}$ \\
\hline & & Halichoeres argus & $\mathrm{LC}$ & $\mathrm{NE}$ \\
\hline & & Hemigymnus fasciatus & $\mathrm{LC}$ & $\mathrm{NE}$ \\
\hline & & Thalassoma jansenii & $\mathrm{LC}$ & $\mathrm{NE}$ \\
\hline & & Thalassoma lunare & $\mathrm{LC}$ & $\mathrm{NE}$ \\
\hline & & Stethojulis trilineata & $\mathrm{LC}$ & $\mathrm{NE}$ \\
\hline & & Thalassoma hardwicke & $\mathrm{LC}$ & $\mathrm{NE}$ \\
\hline
\end{tabular}




\begin{tabular}{|c|c|c|c|c|}
\hline & Lutjanidae (2) & Lutjanus vitta & $\mathrm{LC}$ & $\mathrm{NE}$ \\
\hline & & Lutjanus fulvus & $\mathrm{LC}$ & $\mathrm{NE}$ \\
\hline & Mullidae (1) & Parupeneus trifasciatus & NE & NE \\
\hline & Nemipteridae (1) & Scolopsis lineata & $\mathrm{LC}$ & $\mathrm{NE}$ \\
\hline & Plesiopidae (1) & Plesiops coeruleolineatus & $\mathrm{NE}$ & $\mathrm{NE}$ \\
\hline & Pomacanthidae (3) & Pomacanthus semicirculatus & $\mathrm{LC}$ & NE \\
\hline & & Pomacanthus annularis & LC & NE \\
\hline & & Centropyge eibli & $\mathrm{LC}$ & $\mathrm{NE}$ \\
\hline & Pomacentridae (18) & Abudefduf sordidus & $\mathrm{LC}$ & NE \\
\hline & & Abudefduf vaigiensis & $\mathrm{LC}$ & NE \\
\hline & & Abudefduf septemfasciatus & $\mathrm{LC}$ & $\mathrm{NE}$ \\
\hline & & Pomacentrus chrysurus & $\mathrm{NE}$ & NE \\
\hline & & Pomacentrus moluccensis & $\mathrm{NE}$ & NE \\
\hline & & Plectroglyphidodon leucozonus & $\mathrm{NE}$ & $\mathrm{NE}$ \\
\hline & & Chrysiptera unimaculata & $\mathrm{LC}$ & $\mathrm{NE}$ \\
\hline & & Pomacentrus tripunctatus & $\mathrm{NE}$ & NE \\
\hline & & Plectroglyphidodon dickii & $\mathrm{NE}$ & NE \\
\hline & & Plectroglyphidodon phoenixensis & $\mathrm{NE}$ & NE \\
\hline & & Stegatses nigricans & $\mathrm{NE}$ & $\mathrm{NE}$ \\
\hline & & Chrysiptera brownriggii & $\mathrm{NE}$ & $\mathrm{NE}$ \\
\hline & & Neopomacentrus cyanomos & $\mathrm{NE}$ & $\mathrm{NE}$ \\
\hline & & Amphiprion akallopisos & $\mathrm{LC}$ & $\mathrm{NE}$ \\
\hline & & Chromis opercularis & $\mathrm{NE}$ & $\mathrm{NE}$ \\
\hline & & Amphiprion ocellaris & $\mathrm{NE}$ & NE \\
\hline & & Dascyllus trimaculatus & $\mathrm{NE}$ & $\mathrm{NE}$ \\
\hline & & Neopomacentrus bankieri & $\mathrm{LC}$ & $\mathrm{NE}$ \\
\hline & Scaridae (1) & Scarus flavipectoralis & $\mathrm{LC}$ & NE \\
\hline & Serranidae (2) & Cephalopholis cyanostigma & $\mathrm{LC}$ & $\mathrm{NE}$ \\
\hline & & Grammistes sexlineatus & $\mathrm{LC}$ & $\mathrm{NE}$ \\
\hline & Siganidae (1) & Siganus spinus & $\mathrm{LC}$ & NE \\
\hline & Zanclidae (1) & Zanclus cornutus & $\mathrm{LC}$ & $\mathrm{NE}$ \\
\hline Scorpaeniformes (1) & Scorpaenidae (3) & Scorpaenodes guamensis & LC & NE \\
\hline & & Pterois miles & $\mathrm{LC}$ & $\mathrm{NE}$ \\
\hline & & Dendrochirus zebra & $\mathrm{LC}$ & $\mathrm{NE}$ \\
\hline Syngnathiformes (1) & Syngnathidae (2) & Hippocampus kuda & VU & $\begin{array}{l}\text { Appendix II: international } \\
\text { trade monitored }\end{array}$ \\
\hline & & Corythoichthys intestinalis & $\mathrm{LC}$ & NE \\
\hline Tetraodontiformes (4) & Tetraodontidae (4) & Canthigaster amboinensis & $\mathrm{LC}$ & $\mathrm{NE}$ \\
\hline & & Canthigaster compressa & $\mathrm{LC}$ & NE \\
\hline & & Canthigaster valentinii & $\mathrm{LC}$ & NE \\
\hline & & Chelonodon patoca & $\mathrm{LC}$ & $\mathrm{NE}$ \\
\hline & Balistidae (1) & Pseudobalistes flavimarginatus & $\mathrm{NE}$ & NE \\
\hline & Monacanthidae (1) & Cantherhines dumerilii & $\mathrm{LC}$ & $\mathrm{NE}$ \\
\hline & Ostraciidae (2) & Lactoria cornuta & $\mathrm{NE}$ & NE \\
\hline & & Ostracion cubicus & $\mathrm{NE}$ & $\mathrm{NE}$ \\
\hline
\end{tabular}

Note: $\mathrm{LC}=$ Least Concern $; \mathrm{NE}=$ Not Evaluated

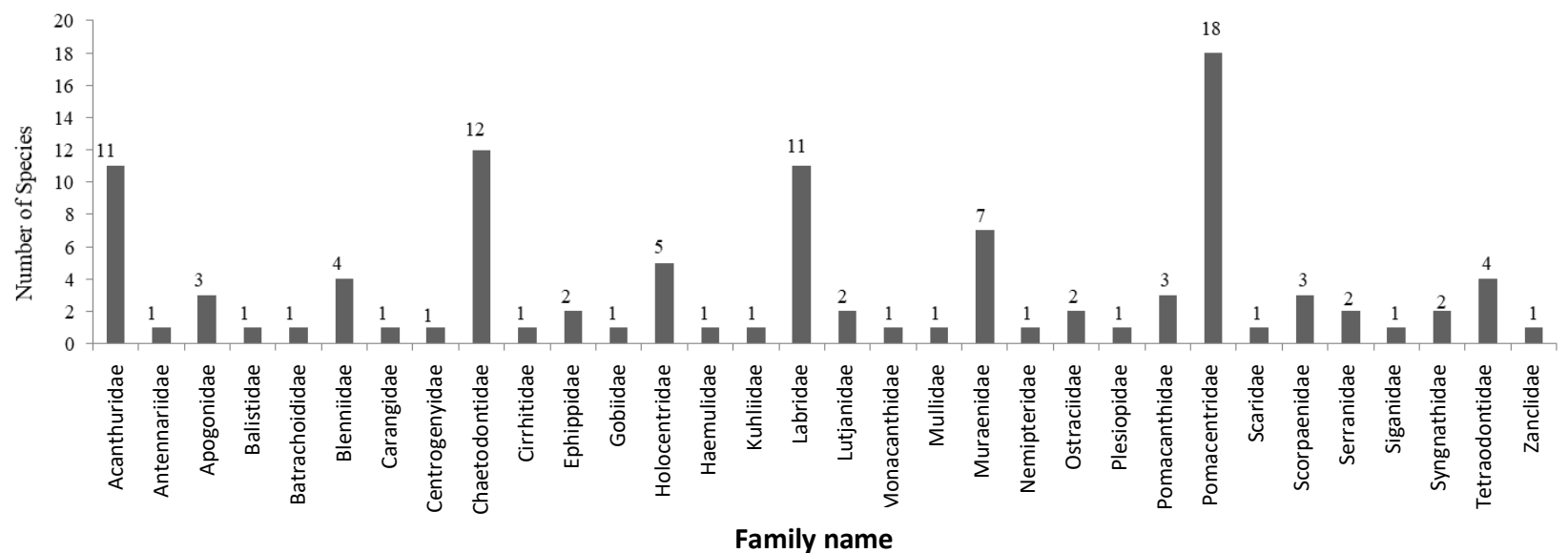

Figure 2. Species number according to family 
Pomacentridae is among the abundant families in Perciformes, with more than 340 species from 29 genera (Jang-Liaw et al. 2002). Members of this family are widely distributed across tropical coral reef ecosystems around the world. A total of 165 Pomacentridae species have been described in Indonesia's marine waters (Froese and Pauly 2019). Therefore, our finding of 18 ornamental species from Pomacentridae on the south coast of Pangandaran strengthens the general acceptance of the abundance of Pomacentridae in terms of the total number of species in this family. A large number of Pomacentridae species are widespread in several Indonesian localities, as has been reported in earlier studies (Sahetapy et al. 2018; Rondonuwu et al. 2013; Sugianti and Mujianto 2013).

Chaetodontidae is also a family with a large number of species and is well known as an ornamental species. According to Allen and Erdmann (2012), members of this family have bright beautiful colors and color patterns. Therefore, it is reasonable that we obtained a large number of Chaetodontidae during our survey. The high taxonomic diversity of Chaetodontidae was also observed by Madduppa et al. (2013), who studied the coral reef fish community in Thousand Islands, Jakarta. The similarity between our study and the study from Maddupa et al. (2013) proves that Chaetodontidae is a large family in Perciformes, and many Chaetodontidae species are wellknown as ornamental species. According to Froese and Pauly (2019), marine Chaetodontidae in Indonesia consists of a total of 65 species. Our results, therefore, strengthen the available data describing the high species diversity of Chaetodontidae.

Labridae are an even more abundant family in Perciformes, with more than 500 species from 60 genera (Mikami 2013), with approximately 196 of these species being described in Indonesia (Froese and Pauly 2019). Here, we obtained a lower number of Labridae species compared to the total number of species that have been described in Indonesia and a lower number than reported by Madduppa et al. (2013). There are at least two possible reasons for this difference. Firstly, our study only focused on marine ornamental fish species, whereas Froese and Pauly (2019) listed all members of Labridae including both non-ornamental and ornamental species. Madduppa et al. (2013) also made surveyed both ornamental and nonornamental Labridae. Secondly, we only sampled ornamental fish from the southern coast of Pangandaran, whereas Froese and Pauly (2019) recorded Labridae species from all over Indonesia. Madduppa et al. (2013) collected Labridae species from more extensive areas in Thousands Islands with more variable habitats. Therefore, for these reasons, we consider the 11 species we obtained in this study to be sufficiently abundant compared to the other families we found.

Acanthuridae is not as abundant as Chaetodontidae, Labridae, or Pomacentridae. A total of 83 Acanthuridae species have been described from around the world divided into six genera (Bernal and Rocha 2011; Randall et al. 2011). A total of 51 marine Acanthuridae species have been identified in Indonesia (Froese and Pauly 2019). Here, we found a lower number of Acanthuridae species than those recorded by Froese and Pauly (2019). The reasons for this difference are similar to those described above for Labridae. However, it should be noted that our number of Labridae was higher than that reported by Madduppa et al. (2013). This difference could be due to the fact that we used different sampling methods. In our study, we collected samples directly from collectors, whereas Madduppa et al. (2013) performed a visual census only, meaning that there is a high likelihood that many fish could be easily missed due to their fast movement, and also perhaps because they were outside the research quadrant.

In general, our results were lower than the number of species described for marine fish species in the world or even from Indonesia. However, since we sampled only marine ornamental fish from a narrower geographic coverage than in previous publications (Bernal and Rocha 2011; Randall et al. 2011; Madduppa et al. 2013; Mikami, 2013; Froese and Pauly 2019), our result provide valuable data for the management of marine ornamental fish resources in Pangandaran Region that is not provided by these previous studies.

Perciformes is a dominant order with 22 families followed by Tetraodontiformes, which has four families. The remaining six orders have one family each. Data showing the total number of families per order are summarized in the pie chart in Figure 3. Our discovery strengthens the general acceptance that Perciformes are the main constituent of Indonesia's marine fish communities. So far, 82 fish families of Perciformes have been identified to inhabit Indonesian waters. At the species level, Perciformes contributes $62 \%$ of the total of Indonesia's marine fish species (Froese and Pauly 2019). Our finding is similar to what was reported by Unsworth et al. (2007) and Madduppa et al. (2013). Moreover, our result provides additional data to strengthen the fact that Perciformes are dominant over other fish orders.

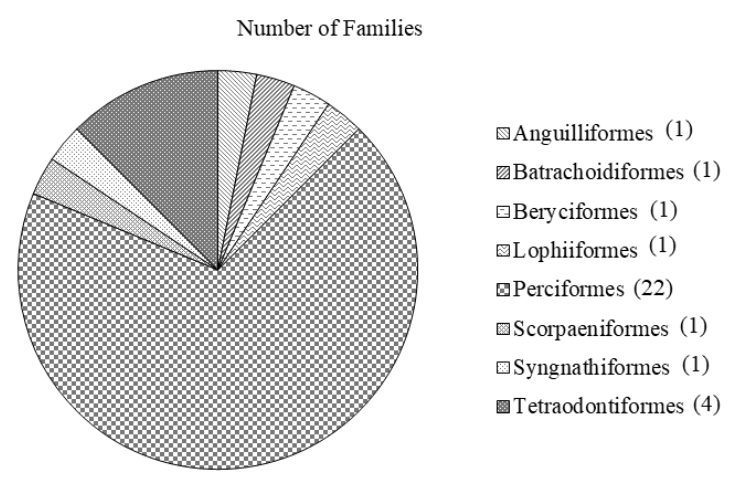

Figure 3. Family number according to order 


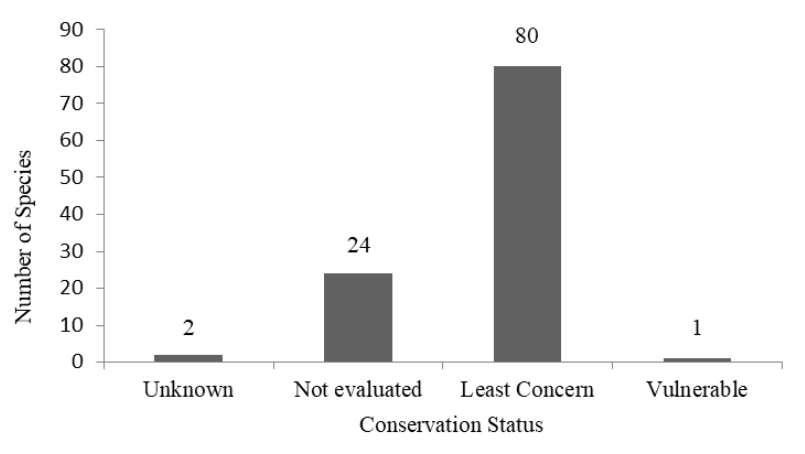

Figure 4. Conservation status according to number of species

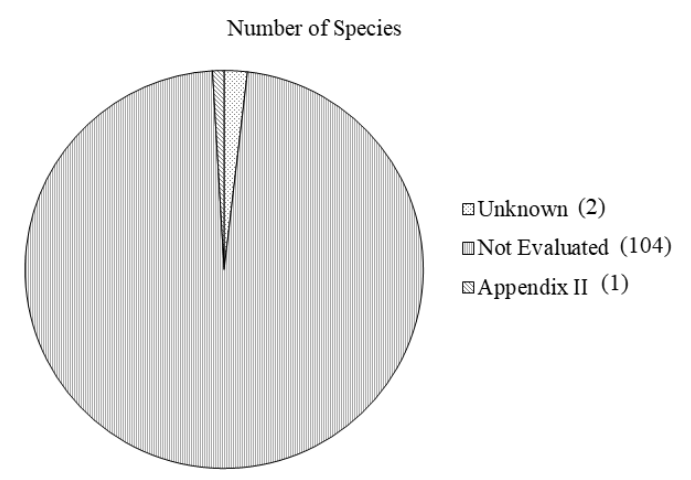

Figure 5. Trade status according to the number of species

\section{Conservation and trade status}

The conservation status of each fish species is shown in Table 1, and the total number of species by conservation status is shown in Figure 4. From Figure 4, we can see that most of the species are categorized in the Least Concern and Not Evaluated conservation categories by the International Union for Conservation of Nature (IUCN), except for Hippocampus kuda. H. kuda is categorized as a vulnerable species by IUCN (Aylesworth 2014). Even, referring to the Ministerial Decree of the Republic of Indonesia No 106/ 2018 and No 20/2018, none of the fish species harvested from Pangandaran coastal waters are listed as protected species under both of these Indonesian laws.

The current conservation status of the fish species obtained during the study, as shown in Figure 4, implies that harvesting and trading of almost species are a legal business, except for Hippocampus kuda, which listed as a Vulnerable species by the IUCN. However, if we restrict our reference to the Ministerial decree of the Republic of Indonesia No 106/ 2018 and No 20/2018, all species can be harvested and traded legally without any prerequisites, including $H$. kuda. However, since the extraction of wildlife resources is occurring daily and hundreds of fishers are involved, and is well-known to occur across Indonesia (Reksodiharjo-Liley and Liley 2007; Halim 2002), the sustainability of marine ornamental fisheries in Pangandaran coastal waters is an important issue and needs to be controlled. This is because there is a possibility that fishing and natural mortalities rates of marine ornamental fish species in Pangandaran coastal waters might outstrip the ability to replenish. This situation is exacerbated by the utilization of destructive fishing practices by fishers when collecting their target species, such as the use of poisonous chemicals and the destruction of the coral habitat when the target specimens are hiding behind the coral. These fishing methods are widely accepted as being harmful and have an adverse impact not only on the target species but also on other species or even to the whole ecosystem (Pet-Soede and Erdmann 1998) and might cause overfishing (Sadovy and Vincent 2002). The situation may worsen if there is no monitoring and supervision from the government.
Therefore, government intervention and enforcement are needed to ensure the sustainable use of marine ornamental fish in the southern coastal region of Pangandaran District.

The international trade status of the marine ornamental fish species obtained during our study in the Pangandaran District is shown in Table 1, and the total number of species for each trade status as provided by Convention on International Trade in Endangered Species (CITES) is summarized in Figure 5.

It can be seen from Figure 5 that most of the marine ornamental species that are harvested and traded in Pangandaran coastal waters are categorized as having a Not Evaluated trade status by CITES (https: //www.cites.org/eng/app/appendices.php). One species, i.e., Hippocampus kuda, is categorized in Appendix II (https: //www.cites.org/eng/app/appendices.php). Two species (Aspidonotus sp. and Gymnothorax sp.) have an unknown trade status. This is because we were unable to identify these specimens at the species level and accordingly we could not define their trade status based on the CITES Appendix. This means that almost all of the species can be legally sold in international trade without any restriction and or prerequisites, except $H$. kuda.

The collection and trade in the species observed in this study is ongoing continuously in the Pangandaran coastal waters. Therefore, monitoring of the marine ornamental fish harvest and trade in Pangandaran coastal waters is needed to ensure sustainable fishing of these resources in the future. Monitoring is crucial for species with a high price (150,000 IDR per individual), such as Paracanthurus hepaticus and Uropterygius polyspilus. Monitoring of the ornamental fish trade is easy because the ornamental fish trade in Pangandaran District follows a general flow consisting of fishermen-first middleman-supplier-exporter. This market flow has been described by ReksodihardjoLiley and Liley (2007) and recently confirmed by Rhyne et al. (2012a) and Fujita et al. (2013).

Target species obtained by collectors on the south coast of Pangandaran (Table 1) are different from the target species collected in Bali (Reksodihardjo-Lilley and Lilley 2007). This means that the south coast of Pangandaran offers different resources of marine ornamental fish and 
provides enrichment in the ornamental fish species trade. The most important finding is that the southern coast of Pangandaran is unique from other regions, and might become iconic in the aquarium trade. During this study, some species of marine ornamental fish harvested from the southern coast of Pangandaran were shipped to fill the market demand in Bali, which could not be fulfilled by local fishermen in Bali (personal interview with collectors). Since no recent data are available from Bali, whether different target species in Pangandaran and Bali as described by Reksodihardjo-Lilley and Lilley (2007) is still occurring or not, continuous monitoring across Indonesia is a vital effort to ensure sustainable fishing of marine ornamental fish in Indonesia.

Special attention must be paid to Hippocampus kuda. That species is not protected under Indonesian law (Ministerial decree the Republic of Indonesia No 106/ 2018), but it is listed as a Vulnerable species (Aylesworth 2014) and is placed in Appendix II of the CITES red list data book. However, fishing of this species is still occurring in Pangandaran coastal waters. Therefore, the trade of $H$. kuda must be vigorously monitored. Vigorous law enforcement and the placement of $H$. kuda on a ministerial decree for the protection of flora and fauna are also urgently needed.

In conclusion, the southern coastal region of Pangandaran has a high potential as a marine ornamental fish resource. Pomacentridae is the family with the highest number of ornamental species traded in Pangandaran District. Two species are categorized as having an unknown conservation status, whereas 24 and 80 species are categorized as having a conservation status of not evaluated and least concern, respectively. In contrast, 2 and 104 species are categorized as having a trade status of unknown and not evaluated, respectively. Hippocampus $k u d a$ was the only species with vulnerable conservation status and is listed in appendix II of CITES.

\section{ACKNOWLEDGEMENTS}

We want to thank the Directorate of Research and Public Services of The Ministry of Research, Technology, and Higher Education of The Republic of Indonesia, which provided the funding to make this study was possible through the Research Scheme of Penelitian Dasar Unggulan Perguruan Tinggi (PDUPT) contract number $\mathrm{P} / 1811 / \mathrm{UN} 23 / 14 / \mathrm{PN} / 2019$. We also wish to thank Jenderal Soedirman University (Unsoed) and Biology Faculty of Unsoed, Purwokerto, Indonesia for the facilities that we utilized during the study. We also thank people for their help during fish collection. Finally, we wish to thank the reviewers for the valuable suggestions and input that have increased the scientific value of this manuscript.

\section{REFERENCES}

Allen GR, Erdmann MV. 2012. Reef Fishes of the East Indies. University of Hawaii Press, Hawaii.
Aylesworth L. 2014. Hippocampus kuda. The IUCN Red List of Threatened Species 2014: e.T10075A16664386. DOI: 10.2305/IUCN.UK.2014-3.RLTS.T10075A16664386.en

Bernal MA, Rocha LA. 2011. Acanthurus tractus Poey, 1860, a valid western Atlantic species of surgeonfish (Teleostei, Acanthuridae), distinct from Acanthurus bahianus Castelnau, 1855. Zootaxa 2905: 63-68.

Central Bureau of Statistics. 2018. Pangandaran Regency in Figure. Central Bureau of Statistics of Ciamis Regency, Ciamis. [Indonesian]

Fadli N, Aidia, Muhammad, Rudi E. 2012. Composition of coral reef fishes in coral transplantation location in Rubiah Island, Sabang City, Aceh. Depik 1 (3): 196-199. [Indonesian]

Fadli N, Muchlisin ZA, Sofyan H, El-Rahimi SA, Dewiyanti I, Pratama FO, Mustari TR, Siti-Aziah MN. 2018. The composition of reefassociated fishes in Ulee Lheue breakwater Banda Aceh, Aceh, Indonesia. IOP Conference Series: Earth Environ Sci 216 (2018) 012021. DOI: 10.1088/1755-1315/216/1/012021.

Firmansyah T, Hasan Z, Afrainto E, Apriliani IM. 2018. Mapping of potential fishing zone for largehead hairtail fish (Trichiurus sp.) in Pangandaran waters, West Java. J Airaha 7 (1): 6-12. [Indonesian]

Froese R, Pauly D. Editors. 2019. FishBase. World Wide Web electronic publication. www.fishbase.org.

Fujita R, Thornhill DJ, Karr K, Cooper CH, Dee LE. 2013. Assessing and managing data-limited ornamental fisheries in coral reefs. Fish Fisheries. DOI: 10.1111/faf.12040.

Gertzen E, Familiar O, Leung B. 2008. Quantifying invasion pathways: fish introductions from the aquarium trade. Can J Fish Aquat Sci 65: 1265-1273.

Halim A. 2002. Adoption of cyanide fishing practice in Indonesia. Ocean Coast Manag 45: 313-323.

Hastuty R, Yonvitner, Andrianto L. 2014. Coral cover and composition of reef fishes inside and outside of marine protected areas, eastern coast of Weh Island, Sabang. Depik 3 (2): 99-107. [Indonesian]

Jang-Liaw N-H, Tang KL, Hui C-F, Shao K-T. 2002. Molecular phylogeny of 48 species of damselfishes (Perciformes: Pomacentridae) using 12S mtDNA sequences. Mol Phylogenet Evol 25: 445-454.

Jones AM, Gardner S, Sinclair W. 2008. Losing 'Nemo': bleaching and collection appear to reduce inshore populations of anemonefishes. J Fish Biol 73: 753-761.

Lunn KE, Moreau MA. 2004. Unmonitored trade in marine ornamental fishes: the case of Indonesia's Banggai cardinalfish (Pterapogon kauderni). Coral Reefs 23 (3): 344-351.

Madduppa HH, Subhan B, Suparyani E, Siregar AM, Arafat D, Tarigan SA, Alimuddin, Khairudi D, Rahmawati F, Bramandito A. 2013. Dynamics of fish diversity across an environmental gradient in the Seribu Islands reefs off Jakarta. Biodiversitas 14 (1): 17-24.

Mayunar. 1996. Economically important of reef fish as export commodities and their cultivation prospects. Oseana 21 (3): 23-31. [Indonesian]

Mikami Y. 2013. Phylogenetic relationship of Labridae species deduced from comparative dissection. Anat Rec 296: 788-797.

Nijman V. 2010. An overview of international wildlife trade from Southeast Asia. Biodivers Conserv 19: 1101-1114.

Pet-Soede L, Erdmann M. 1998. An overview and comparison of destructive fishing practices in Indonesia. SPC Live Reef Fish Inform Bull 4: 26-38.

Prahoro P, Adrim M. 1988. Marine ornamental fish resources in the southern coast of West Java. J Penelitian Perikanan Laut 49: 1-11. [Indonesian]

Randall JE, DiBattista JD, Wilcox C. 2011. Acanthurus nigros Günther, a valid species of surgeonfish, distinct from the Hawaiian A. nigroris Valenciennes. Pac Sci 65: 265-275.

Reksodihardjo-Liley G, Liley R. 2007. Towards a sustainable marine aquarium trade: An Indonesian perspective. SPC Live Reef Fish Inform Bull 17: 11-19.

Rhyne AL, Tlusty MF, Schofield PJ, Kaufman L, Morris JA Jr, Bruckner AW. 2012a. Revealing the appetite of the marine aquarium fish trade: the volume and biodiversity of fish imported into the United States. PLoS ONE 7 (5): e35808. DOI: 10.1371/journal.pone.0035808.

Rhyne AL, Tlusty MF, Kaufman L. 2012b. Long-term trends of coral imports into the United States indicate future opportunities for ecosystem and societal benefits. Conserv Lett 5: 478-485.

Rubec PJ, Cruz F, Pratt V, Oellers R, McCullough B, Lallo F. 2001. Cyanide-free net caught fish for the marine aquarium trade. Aquarium Sci Conserv 3: 37-51. 
Rondonuwu AB, Tombokan JL, Rembet UNWJ. 2013. Distribution and abundance of coral fishes the family Pomacentridae in coral reef waters Poopoh Village, Sub-District Tombariri, Minahasa Regency. J Ilmiah Platax 1 (2): 87-92. [Indonesian]

Sadovy YJ, Vincent ACJ. 2002. Ecological issues and the trades in live reef fishes. In: Sale PF (ed.). Coral Reef Fishes: Dynamics and Diversity in A Complex Ecosystem. Academic Press, San Diego.

Sahetapy D, Retraubun ASW, Bengen DG, Abrahamsz J. 2018. Coral reef fishes of Tuhaha Bay, Saparua Island, Maluku Province, Indonesia. Intl J Fisheries Aquat Stud 6 (2): 105-109.

Shuman CS, Hodgson G, Ambrose RF. 2004. Managing the marine aquarium trade: is eco-certification the answer? Environ Conserv 31 (4): 339-348.

Sugianti Y, Mujianto. 2013. Biodiversity of coral fish in Karimunjawa National Parks waters, Jepara. Bawal 5 (1): 23-31. [Indonesian]

Tlusty M. 2002. The benefits and risks of aquacultural production for the aquarium trade. Aquaculture 205: 203-219.
Unsworth RKF, Wylie E, Smith DJ, Bell JJ. 2007. Diel trophic structuring of seagrass bed fish assemblages in the Wakatobi Marine National Park, Indonesia. Estuar Coast Shelf Sci 72: 81-88.

Wabnitz C, Taylor M, Green E, Razak T. 2003. From Ocean to Aquarium. UNEP-WCMC, Cambridge, UK.

Wahyudin Y. 2011. Characteristics of coastal and marine resources of the Palabuhanratu bay areas, Sukabumi Regency, West Java. Bonorowo Wetlands 1 (1): 19-32. [Indonesian]

Wood E. 2001. Collection of Coral Reef Fish for Aquaria: Global Trade, Conservation Issues and Management Strategies. Marine Conservation Society, United Kingdom.

Yusuf M. 2013. Coral reefs condition and fish potential in Karimunjawa National Park, Jepara Regency. Buletin Oseanografi Marina 2: 54-60. [Indonesian]

Ziemann DA. 2001. The potential for the restoration of marine ornamental fish populations through hatchery releases. Aquarium Sci Conserv 3: 107-117. 